\title{
The importance and effectiveness of walking training in cardiac rehabilitation with special regard to patients after cardiac surgery
}

\author{
Znaczenie i użyteczność treningu marszowego w rehabilitacji \\ kardiologicznej ze szczególnym uwzględnieniem chorych po zabiegach \\ kardiochirurgicznych
}

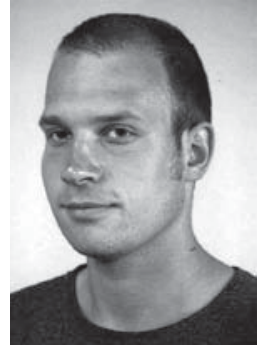

\author{
Piotr Kocur ${ }^{1}$, Monika Krzywicka-Michałowska², Małgorzata Wilk², Piotr Dylewicz ${ }^{2}$ \\ ${ }^{1}$ Katedra Rehabilitacji Narządu Ruchu Akademii Wychowania Fizycznego w Poznaniu \\ ${ }^{2}$ Katedra Rehabilitacji Kardiologicznej Akademii Wychowania Fizycznego w Poznaniu
}

Kardiochirurgia i Torakochirurgia Polska 2012; 9 (4): 481-485

\begin{abstract}
Rehabilitation based on physical exercise should focus not only on improving the current level of physical fitness, but also on increasing patients' awareness and forming a habit of physical activity as a form of secondary cardiovascular disease prevention. The aim of this article is to review the most current publications on this subject and point to the importance of walking training in successful cardiac rehabilitation, even for cardiac surgery patients. The authors of this article postulate the necessity of propagating simple forms of physical activity, such as walking training, as an important factor in reducing the incidence and recurrence of cardiovascular diseases as well as the resulting mortality rate.
\end{abstract}

Key words: walking training, physiotherapy, cardiovascular diseases.

\section{Is walking training a valuable form of prevention and rehabilitation?}

Walking is undoubtedly the most common and, therefore, the most natural form of physical activity. Patients can practice it without supervision, even after leaving the hospital. One of the many advantages of walking is the fact that it activates more than half of the muscles of the body, especially its lower parts. At the same time, the strain on the lower limb joints is less significant than in the case of running or jogging. This is especially important for the elderly and patients with neuromuscular and orthopedic conditions. While walking, the musculoskeletal system

\section{Streszczenie}

Rehabilitacja, oparta na ćwiczeniach fizycznych, powinna być ukierunkowana na bieżącą poprawę sprawności fizycznej, ale również na pozostawienie trwałego śladu w świadomości pacjentów i kształtowaniu nawyku aktywności ruchowej jako formy profilaktyki wtórnej chorób układu krążenia. W niniejszym artykule dokonano przeglądu literatury oraz wskazano na szczególne znaczenie treningu marszowego w skutecznym procesie rehabilitacji pacjentów kardiologicznych, w tym po zabiegach kardiochirurgicznych. W opinii autorów konieczne są działania zmierzające do rozpropagowania prostych form aktywności ruchowej, takich jak trening marszowy, jako ważnego czynnika redukującego liczbę zachorowań, nawrotów choroby i zgonów wynikających z chorób układu krążenia.

Słowa kluczowe: trening marszowy, fizjoterapia, choroby układu krążenia.

is activated to a similar degree as during such activities as swimming or riding a bicycle. Walking, as opposed to running, is an exceptionally safe activity, since it involves having one leg always in contact with the ground, which minimizes the risk of falls and injuries [1, 2].

Research shows that the frequency and pace of walking are inversely proportional to the incidence of cardiac disease and mortality [3]. The economic advantages of walking are also worth mentioning. Apart from comfortable shoes, no expensive special equipment is required. Therefore, financial status has no influence on the possibility of commencing walking training in order to increase physical activity and improve health [4]. 
The World Health Organization concluded that walking is the basic form of physical activity necessary for maintaining good health and should be an inseparable part of a healthy everyday lifestyle, including working days [5]. It is difficult to unambiguously state whether engaging in regular walking training may by itself ensure the maintenance of a certain level of health and physical condition. However, in conjunction with a hygienic lifestyle, walking seems to be a sufficient way of maintaining the aforementioned factors at "satisfactory" levels.

\section{Walking training and its special place in cardiac rehabilitation}

It is often emphasized that walking is the best and also one of the first activities which can be employed at the early stage of cardiac rehabilitation. This is especially true for those patients who do not have the opportunity to undergo rehabilitation in stationary and clinical conditions. Walking training (WT), which can be considered an activity of moderate intensity, provides similar health benefits to other, more intense exercises, while posing less danger of injury and sudden death [2-7]. Research demonstrates that the majority of patients, apart from those participating in organized forms of exercise, engage in only minimal activity in their spare time [7].

Walking training should become a standard in cardiac rehabilitation. It is especially recommended for patients who cannot participate in supervised rehabilitation, as well as a complement for the latter. For 30 years it has been known that walking training helps achieve "maximum success at minimum risk" [8]. Studies show that regular WT improved $\mathrm{VO}_{2 \text { max }}$ in middle-aged women by 9-28\% [9]. The change in cardiopulmonary function is strictly dependent on the pace of walking. The volume of air exhaled increases from 7-9 $\mathrm{l} / \mathrm{min}$ while resting to $20-30 \mathrm{l} / \mathrm{min}$ during a slow walk and $35-50 \mathrm{l} / \mathrm{min}$ during a fast walk $[2,10]$. At the early stage of rehabilitation, walking can significantly improve such important factors as the respiratory quotient and maximal oxygen consumption [11]. It has been known for years that walking is one of the first forms of physical activity to be recommended after such serious surgery as a heart transplant [12]. In an extensive meta-analysis concerning the influence of walking on arterial pressure, which covered over 30 years of research (1966-1998), 24 studies and about 700 subjects, it was demonstrated that walking training reduces resting systolic blood pressure by $3 \mathrm{mmHg}(-5 \mathrm{~mm} \mathrm{Hg}$ to $-2 \mathrm{~mm} \mathrm{Hg}$ ) and resting diastolic blood pressure by $2 \mathrm{~mm} \mathrm{Hg}$ $(-3 \mathrm{~mm} \mathrm{Hg}$ to $-1 \mathrm{~mm} \mathrm{Hg}$ ) on average [13]. This may be the reason why it is one of the first activities recommended for patients suffering from such conditions [14].

It was observed 15 years ago that 12 -week WT has a bearing on the improvement of fitness in cardiac surgery patients (CABG) [15]. Other studies show the effectiveness of WT after CABG procedures with training taking place 6 times a day and lasting 6 minutes each time [16]. Another study focused on the influence of WT within one year, with training sessions taking place 5 times a week. The analysis covered 7,000 cardiac patients, 2,000 of whom were men who had undergone coronary artery bypass graft surgery. It demonstrated the improvement of the patients' physical fitness expressed as the increase of peak $\mathrm{VO}_{2}$ and, most importantly, the distance and pace of their walks. The research indicated that the latter two factors have a higher forecast value than peak $\mathrm{VO}_{2}$ [17]. It is especially worth emphasizing that there are some rehabilitation programs which recommend starting the walking training within the first 6 days after surgery and increasing the walking distance from 100 to even 600 meters after 3-6 days [18]. Other studies clearly show that WT of moderate intensity is the most effective form of training for improving fitness at the early stage of CABG rehabilitation. At the same time, no significant changes were noted between groups with different forms of training after 4 weeks from the end of the hospitalization period [19]. It is worth mentioning that the low-risk patients awaiting an operation who had training sessions twice a week stayed in the hospital for a shorter period of time after the surgical intervention. It may be advisable to consider and recommend walking training even before surgical procedures [20].

\section{The influence of walking training on metabolic risk factors}

Some studies have indicated that WT for cardiac patients should be conducted at least 3 times a week and last from 40 to 60 minutes. Such a program can lead to decreased body mass and BMI, as well as a lower total amount of cholesterol and triglycerides, and may extend the distance covered during the 6-minute walking test [21]. Concurrently, it has been noted that walking may improve physiological parameters, such as fat mass and body mass content, under the condition, however, that the training is longer than 30 min per session or 150 min per week. Whether the aforementioned physiological parameters could be successfully improved by extending the length of the training sessions (to 60-90 min per session) and the frequency of the training (to 3 times a week) $[6,7,22,23]$ is still a matter of debate. It has been established that WT conducted regularly (3-5 times a week) for a period of 10 to 40 weeks (frequency of training inversely proportional to total training duration) leads to a $5-6 \%$ decrease in the total cholesterol and LDL fraction levels [24]. The professional literature discusses in a relatively detailed manner the possibility of employing WT in groups characterized by low physical activity awareness. WT efficacy in obese persons is influenced not only by the duration of the program but also by factors such as its total volume. It has been noted that obese patients suffering from ischemic heart disease, after a 4-month regime of 60-90 minute sessions 5-7 times a week, experienced decreases in body mass $(-4.6 \mathrm{~kg})$, total body fat amount $(-3.6 \mathrm{~kg})$, fat mass percentage $(-2.9 \%)$ and waist circumference $(-5.6 \mathrm{~cm})$. Moreover, the level of lean mass was retained and the amount of cholesterol and triglycerides in the blood was decreased [25]. Studies concerning various types of walking training, conducted 
among women leading sedentary lifestyles, have demonstrated that WT conducted 3 times a day for $10 \mathrm{~min}$ for a period of 10 weeks yielded similar improvements in physiological parameters $\left(\mathrm{VO}_{2}\right.$ max , lactate concentration after training) and resulted in a similar decrease in fat mass as the WT conducted for the same period of time and with the same frequency, but concentrated in a single 30-minute session per day. Based on the obtained results, Aldred et al. concluded that while the 12 -week WT program conducted among middle-aged women leading sedentary lifestyles did improve exercise tolerance and resulted in a decrease of fat mass, it did not change the blood levels of triglycerides and lipids in a statistically significant manner [26].

Summing up this part of the discussion, it is worthwhile to remember that even walking at a very slow pace $(2-3 \mathrm{~km} / \mathrm{h})$ allows everyone to reach energy expenditure levels of about 2 MET (1 MET = $1 \mathrm{kcal} / \mathrm{kg} / \mathrm{h}$ or $3.5 \mathrm{ml} \mathrm{O} / \mathrm{kg} / \mathrm{min}$ ) [27]. Walking at a pace of $4-5 \mathrm{~km} / \mathrm{h}$ raises metabolism (expressed as the level of energy expenditure) by ca. $3-4 \mathrm{kcal} / \mathrm{min}$ in relation to resting metabolism (Table I) [28]. At this point, it should be noted that the energy cost of walking at a very slow or a very high pace is quite difficult to evaluate. However, walking at a pace of 3 to $6 \mathrm{~km} / \mathrm{h}$ raises the energy expenditure linearly as a function of the studied person's body mass. The expenditure also depends on the sex of the exercising person. An average man ( $\sim 80 \mathrm{~kg}$ ) will use ca. $60 \%$ more energy than an average woman $(\sim 50 \mathrm{~kg})$ walking at the same speed.

It can, therefore, be stated that activity of light to medium intensity, such as various types of walking training, is sufficient (as well as safer) for cardiac patients and obese persons. There remains a problem of accurate assessment and precise control of the intensity level for this form of exercise. Thus, the minimal effective dose of walking training for attaining adequate endurance improvement and heart disease prevention is still a matter of discussion.

\section{How to dose walking training?}

The pace of walking training can be adjusted at will, which makes it difficult to assess its level of intensity. It

Tab. I. Estimated energy cost of walking at a medium speed on flat terrain (and on terrain of varying slope) expressed in metabolic equivalent units - MET (adopted after [29])

\begin{tabular}{lcccccc} 
& \multicolumn{7}{c}{ Speed $(\mathrm{km} / \mathrm{h})$} \\
\cline { 2 - 7 } 0 & $\sim 2.7$ & $\sim 3.2$ & $\sim 4.0$ & $\sim 4.8$ & $\sim 5.4$ & $\sim 6.0$ \\
\hline 2.5 & 2.3 & 2.5 & 2.9 & 3.3 & 3.6 & 3.9 \\
\hline 5.0 & 2.9 & 3.2 & 3.8 & 4.3 & 4.8 & 5.2 \\
\hline 7.5 & 3.5 & 3.9 & 4.6 & 5.4 & 5.9 & 6.5 \\
\hline 10.0 & 4.1 & 4.6 & 5.5 & 6.4 & 7.1 & 7.8 \\
\hline 12.5 & 4.6 & 5.3 & 6.3 & 7.4 & 8.3 & 9.1 \\
\hline 15.0 & 5.2 & 6.0 & 7.2 & 8.5 & 9.5 & 10.4 \\
\hline 17.5 & 5.8 & 6.6 & 8.1 & 9.5 & 10.6 & 11.7 \\
\hline 20.0 & 6.4 & 7.3 & 8.9 & 10.5 & 11.8 & 12.9 \\
\hline & 7.0 & 8.0 & 9.8 & 11.6 & 13.0 & 14.2 \\
\hline
\end{tabular}

has been established that the volume of consumed oxygen rises linearly and predictably for walking at a medium pace $(50-100 \mathrm{~m} / \mathrm{min}-3.6 \mathrm{~km} / \mathrm{h})$, but begins to rise rapidly above this speed. It can, therefore, be assumed that oxygen consumption expressed in $\mathrm{ml} / \mathrm{kg} / \mathrm{min}$ or in MET can be assessed relatively precisely for the aforementioned walking speed of the examined person. Many studies indicate that walking of average intensity, also described as brisk walking, is of considerable significance in disease prevention, and this is especially true for cardiovascular diseases. A study was conducted to precisely evaluate the influence of controlled walking training (patients walking a distance of 1 mile as fast as possible) on the training heart rate at different stages of rehabilitation. It was discovered that, independently of the stage of rehabilitation, $90 \%$ of men and $100 \%$ of women reach a heart rate of $>70 \%$ of maximum $\left(H R_{\max }\right)$, defined by the authors as the minimal level required for successful aerobic endurance training and for lowering the heart rate. Significantly, the test was conducted with the desired level of exertion (Borg scale) at 12 points for men and 13.4 for women [29].

At the same time it should be observed that, according to some normograms, brisk walking at a speed of $6 \mathrm{~km} / \mathrm{h}$ raises the heart rate of the average healthy middle-aged person to $135 \mathrm{bpm}\left(60-80 \% \mathrm{HR}_{\max }\right)$. Considering the level of exertion and the risk of death for persons with cardiovascular diseases and for patients recovering from thoracic surgery, this speed would be too high for rehabilitation training. Some recommendations indicate that improving exertion tolerance may be successfully attained by gradually raising the training load from $10 \mathrm{~km}$ per week covered at a speed of $13 \mathrm{~min} / \mathrm{km}(4.6 \mathrm{~km} / \mathrm{h})$ to $21 \mathrm{~km}$ per week at a speed of $11.5 \mathrm{~min} / \mathrm{km}(5.2 \mathrm{~km} / \mathrm{h})$. As can be observed, gradually increasing the training load, which is already employed in cardiac rehabilitation programs, can also be applied to walking training [30]. Our own studies have also indicated that even short periods of walking training resulted in significant exertion tolerance improvements [31]. Earlier publications focused mostly on walking training conducted for longer periods of time. Some authors claim, based on their research, that the intensity of the training should amount to $45-55 \% \mathrm{VO}_{2 \max }$ [32], while others have concluded that a $\mathrm{VO}_{2}$ reserve of $30-45 \%(\sim 30-45 \% \mathrm{HR}$ reserve or $60-69 \%$ of peak HR) is sufficient [33]. Walking has also been studied as a method of primary prevention for overweight persons with high risk of myocardial infarction. Similar benefits have been observed in a group conducting walking training of light intensity $\left(40-50 \% \mathrm{VO}_{2}\right.$ max $)$, covering a weekly distance of $19 \mathrm{~km}$ per week, in comparison to a group that covered the same weekly distance, but at a higher intensity $\left(70-80 \% \mathrm{VO}_{2 \text { max }}\right)$ [34].

It is worthwhile to note at this point that if the volume of oxygen consumed while walking at a medium speed (4.8 $\mathrm{km} / \mathrm{h}$ ) is within the range of $13 \mathrm{ml} / \mathrm{min} / \mathrm{kg}$, then for a 25 -year-old person this would amount to ca. $30 \%$ of their $\mathrm{VO}_{2} \max$ and would only result in a slight strain on the body. However, each decade of life results in a decrease in one's $\mathrm{VO}_{2 \text { max }}$ by 
ca. $5 \mathrm{ml} / \mathrm{kg} / \mathrm{min}$ [7]. Therefore, walking of the same intensity would be endurance training for elderly persons, bringing them to $50 \%$ of their maximal oxygen uptake level.

\section{Conclusions}

Summing up the present state of knowledge, we can assume that walking training applied as a form of primary and secondary prevention for cardiovascular diseases should be conducted based on the recommendations presented in Table II.

At the same time, the rehabilitation period after serious illness events, particularly after cardiac surgery, requires a more careful and individualized approach even for such forms of exercise as walking training. The patients must, nonetheless, gradually increase their physical activity under the guidance of physiotherapists. Lack of properly dosed exercise may lead to irreversible structural changes of the locomotor system and lower the patient's physical endurance, which significantly increases the risk of their death.

The importance of monitoring the frequency of the cardiac rhythm for planning a walking training program should also be stressed at this point. ECG monitoring is particularly significant at the early stages of rehabilitation, especially for patients recovering from cardiac surgery. It is vital for patients beginning to conduct their walking training on their own, not only to establish their maximal allowable heart rate, but also to acquaint themselves with the Borg scale and to establish the appropriate maximal weekly distance, frequency of training, and number of training units per day or per week.

As in all other fields of medical science, rehabilitation professionals continue their search for the most effective and the safest methods of treating their patients. The constant need for striking this balance results in frequent changes to the therapeutic procedure. New technical solutions and training methods in cardiac rehabilitation frequently improve the effects of treatment and rehabilitation, and increase the level of the patients' comfort during the difficult time of hospitalization. All too often the simpler solutions are forgotten, even though they may be of use to the patients not only during their stationary rehabilitation, but also after its completion. The selection of studies presented above indicates that walking is a very effective therapeutic tool in cardiac rehabilitation, including cardiac surgery recovery, and is simply irreplaceable as a preventive measure.

\section{Literature}

1. Perry J, Burnfield JM. Gait analysis. Normal and pathologic function. SLACK Incorporated, Thorofare 2010; 49-163.

2. Hardman AE, Morris JN. Walking to health. Br J Sports Med 1998; 32: 184.

3. Davey Smith G, Shipley MJ, Batty GD, Morris JN, Marmot M. Physical activity and cause-specific mortality in the Whitehall study. Public Health 2000; 114: 308-315.

4. Siegel PZ, Brackbill RM, Heath GW. The epidemiology of walking for exercise: implications for promoting activity among sedentary groups. Am J Public Health 1995; 85: 706-710.

5. World Health Organization. Physical Activity and Health in Europe. WHO Regional Office for Europe, 2006; 3-7.
Tab. II. Parameters of walking training which can be applied to primary and secondary cardiac prevention

\begin{tabular}{ll} 
Parameters & Value \\
Intensity & $12-13$ Borg scale \\
& $40 \% \mathrm{HRR}^{*}$ \\
& $60 \% \mathrm{HRR}^{* *}$ \\
\hline Walking speed & $2-3 \mathrm{~km} / \mathrm{h}=30-20 \mathrm{~min} / \mathrm{km}^{*}$ \\
& $4-5 \mathrm{~km} / \mathrm{h}=15-12 \mathrm{~min} / \mathrm{km}^{* *}$ \\
\hline Frequency & $4-5$ times per week \\
& $5-7$ times per week \\
\hline Time & Inversely proportional to the frequency \\
& training unit: $1 \mathrm{~h}^{*}$ \\
& $1-2 \mathrm{~h}^{* *}$ \\
total number of hours: $4 \mathrm{~h}^{*}$ \\
& $5+\mathrm{h}^{* *}$ \\
\hline Weekly distance in & $8+\mathrm{km}^{*}$ \\
kilometers & $20+\mathrm{km}^{* *}$ \\
\hline
\end{tabular}

* high-risk patients

** low-risk patients

$+H R R$ - heart rate reserve - the difference between the maximal heart rate

(HRmax) and the resting heart rate (HR rest) calculated with the formula HRR = $\%$ (HRmax - HRrest) + HRrest

6. Tully MA, Cupples ME, Chan WS, McGlade K, Young IS. Brisk walking, fitness and cardiovascular risk: A randomized controlled trial in primary care. Prev Med 2005; 41: 622-662.

7. Franklin B. Walking: the undervalued prescription. Prev Cardiol 2006; 9: 56-59.

8. Harrington KA, Smith KH, Schumacher M, Lunsford BR, Watson KL, Selvester $\mathrm{RH}$. Cardiac rehabilitation: evaluation and intervention less than 6 weeks after myocardial infarction. Arch Phys Med Rehabil 1981; 62: 151-155.

9. Hardman AE, Jones PR, Norgan NG, Hudson A. Brisk walking improves endurance fitness without changing body fatness in previously sedentary women. Eur J Appl Physiol Occup Physiol 1992; 65: 354-359.

10. Porcari J, McCarron R, Kline G, Freedson P, Ward A, Ross J, Rippe J. Is fast walking an adequate aerobic training stimulus for 30- to 69-year men and women? Physician Sportsmed 1987; 15: 119-129.

11. Tsuji M, Saito S, Ando T, Moriuchi M, Tamura Y, Tanigawa N, Ozawa Y, Hatano $\mathrm{M}$, Horie T, Ookawa N. The clinical role of anaerobic threshold in physical training of patients with recent myocardial infarction. J Cardiol 1990; 20: 275-282.

12. Niset G, Hermans L, Depelchin P. Exercise and heart transplantation. A review. Sports Med 1991; 12: 359-379.

13. Kelley GA, Kelley KS, Tran ZV. Walking and resting blood pressure in adults: a meta-analysis. Prev Med 2001; 33: 120-127.

14. Stewart K. Exercise training and the cardiovascular consequences of type 2 diabetes and hypertension: plausible mechanisms for improving cardiovascular health. JAMA 2002; 288: 1622-1631.

15. Goodman J, Pallandi D, Reading J, Plyley MJ, Liu PP, Kavanagh T. Central and peripheral adaptations after 12 weeks of exercise training in post-coronary artery bypass surgery patients. J Cardiopulm Rehabil 1999; 19: 144-150.

16. Wolszakiewicz J, Bilinska M, Foss-Nieradko B, Wrona M, Piotrowicz R. Walking training as a part of early phase of cardiac rehabilitation in patients post coronary artery bypass grafting. Postępy Rehabil 2006; 20: 5-10.

17. Kavanagh T, Hamm LF, Beyene J, Mertens DJ, Kennedy J, Campbell R, Fallah S, Shephard RJ. Usefulness of improvement in walking distance versus peak oxygen uptake in predicting prognosis after myocardial infarction and/or coronary artery bypass grafting in men. Am J Cardiol 2008; 101: 1423-1427.

18. Stein R, Maia CP, Silveira AD, Chiappa GR, Myers J, Ribeiro JP. Inspiratory muscle strength as a determinant of functional capacity early after coronary artery bypass graft surgery. Arch Phys Med Rehabil 2009; 90: 1685-1691.

19. Hirschhorn AD, Richards D, Mungovan SF, Morris NR, Adams L. Supervised moderate intensity exercise improves distance walked at hospital discharge following coronary artery bypass graft surgery - a randomised controlled trial. Heart Lung Circ 2008; 17: 129-138.

20. Arthur HM, Daniels C, McKelvie R, Hirsh J, Rush B. Effect of a preoperative intervention on preoperative and postoperative outcomes in low-risk patients awaiting elective coronary artery bypass graft surgery. A randomized, controlled trial. Ann Intern Med 2000; 133: 253-262. 
21. Oka R, Sanders M. The impact of exercise on body composition and nutritiona intake in patients with heart failure. Prog Cardiovasc Nurs 2005; 20: 148-154.

22. Lee IM, Rexrode KM, Cook NR, Manson JE, Buring JE. Physical activity and coronary heart disease in women. JAMA 2001; 285: 1447-1454.

23. Pate RR, Pratt M, Blair SN, Haskell WL, Macera CA, Bouchard C, Buchner D, Ettinger W, Heath GW, King AC, Kriska A, Leon A, Marcus B, Morris J, Paffenbarger R, Patrick, K, Pollock M, Rippe J, Sallis J, Wilmore H. Physical activity and public health: a recommendation from the centers for disease control and prevention and the American College of Sports Medicine. JAMA 1995; 273: 402-407.

24. Kelly G, Kelly K, Tran Z. Walking, lipids, and lipoproteins: a meta-analysis of randomized controlled trials. Prev Med 2004; 38: 651-661.

25. Savage PD, Brochu M, Poehlman ET, Ades PA. Reduction in obesity and coronary risk factors after high caloric exercise training in overweight coronary patients. Am Heart J 2003; 146: 317-323.

26. Aldred HE, Hardman AE, Taylor S. Influence of 12 weeks of training by brisk walking on postprandial lipemia and insulinemia in sedentary middle-aged women. Metabolism 1995; 44: 390-397.

27. Franklin BA, Pamatmat A, Johnson S, Scherf J, Mitchell M, Rubenfire M. Metabolic cost of extremely slow walking in cardiac patients: implications for exercise testing and training. Arch Phys Med Rehabil 1983; 64: 64-65.

28. American College of Sports Medicine. ACSM`s guidelines for exercise testing and prescription. $8^{\text {th }}$ ed. Lippincott Williams \& Wilkins, Baltimore 2009: 300-312.
29. Quell KJ, Porcari JP, Franklin BA, Foster C, Andreuzzi RA, Anthony RM. Is brisk walking an adequate aerobic training stimulus for cardiac patients? Chest 2002; 122: 1852-1856.

30. Hardman AE, Jones PR, Norgan NG, Hudson A. Brisk walking improves endurance fitness without changing body fatness in previously sedentary women. Eur J Appl Physiol Occup Physiol 1992; 65: 354-359.

31. Kocur P, Deskur-Smielecka E, Wilk M, Dylewicz P. Effects of Nordic walk ing training on exercise capacity and fitness in men participating in early, short-term inpatient cardiac rehabilitation after an acute coronary syndrome - a controlled trial. Clin Rehabil 2009; 23: 995-1004.

32. Asikainen TM, Miilunpalo S, Oja P, Rinne M, Pasanen M, Uusi-Rasi K, Vuori I. Randomised, controlled walking trials in postmenopausal women: the minimum dose to improve aerobic fitness? Br J Sports Med 2002; 36: 189-194.

33. Swain D, Franklin B. VO(2) reserve and the minimal intensity for improving cardiorespiratory fitness. Med Sci Sports Exerc 2002; 34: 152-157.

34. Duscha BD, Slentz CA, Johnson JL, Houmard JA, Bensimhon DR, Knetzger KJ, Kraus WE. Effects of exercise training amount and intensity of peak oxygen consumption in middle - age men and women at risk for cardiovascular disease. Chest 2005; 128: 2788-2793. 